\section{Effect of the Striga Germination Stimulant on the Respiration of Striga Seeds}

THE demonstration by Vallance ${ }^{1}$ of the effect of the stimulant solution on the respiration of Striga seeds is a matter of some importance. Vallance, however, suggests that this effect is independent of that described by Brown, Robinson and Johnson ${ }^{2}$, who showed that the Striga stimulant may promote extension growth.

Recent work has shown (a) that extension does not occur under anaerobic conditions ${ }^{3} ;(b)$ that it does not occur in the presence of respiratory poisons ${ }^{4}$; (c) that heteroauxin promotes respiration in the coleoptile ${ }^{5} ;(d)$ that many respiratory stimulants also increase extension ${ }^{6}$; and $(e)$ that respiration normally increases throughout the course of extension?

Clearly, a vigorous respiration is required for extension growth, and in appropriate tissue increases in respiration are likely to be accompanied by corresponding increases in extension. With Striga we suggest that the primary effect may be on respiration, and that as a result extension is promoted. Vallance finds that the increase in respiration may occur when germination is not involved. This, we further suggest, may indicate that other conditions must also be fulfilled before the primary effect in respiration can influence extension.

\section{R. Brown}

E. ROBINSON

Botany Department,

University, Leeds.

Nov. 9.

${ }^{1}$ Vallance, K. B., Nature, 164, 802 (1949).

2 Brown, R., Robinson, E., and Johnson, A. W., Nature, 163, 842 (1949).

3 Bonner, J., J. Gen. Physiol., 17, 63 (1934).

- Bonner, J., J. Gen. Physiol., 20, 1 (1937).

s Commoner, B., and Thimann, K. V., J. Gen. Physiol, 24, 279 (1941).

- Thimann, K. V., and Bonner, W. D., Amer. J. Bot., 35, 271 (1948)

? Brown, R., and Sutcliffe, J. F., J. Exper. Bot. (in the press).

\section{Testing the Lactation-stimulating Factor in Fenugreek Oil for Sex Hormone Activities}

IN view of the lactation-stimulating properties attributed to synthetic œstrogens ${ }^{1,2}$ and to testosteron $\theta^{3}$, and the possible relation between lactation, as one of the factors, and the development of mammary cancer ${ }^{4}$, the lactation-stimulating factor ${ }^{5,6}$ in the oil obtained from fenugreek (Trigonella Franum Grcecum) seeds was tested for sex hormone activities.

Tested for œstrogenic activity in ovariectomized mice and rats by oral administration or subcutaneous injection of ten to fifteen times the lactation-stimulating dose of the oil (three drops daily administered orally to adult lactating female rats), or of the active material (the unsaponifiable fraction) dissolved in the fenugreek oil or sesame oil, no cestrogenic activity could be traced. Tested for testosterone-like activity by Robson's method?, the lactation-stimulating factor did not show corresponding activity.

Using progesterone as a control, no progesteronelike activity was shown by the lactation-stimulating factor when administered by subcutaneous injection to ovariectomized mature rabbits ${ }^{8}$ (average weight of rabbits $1.5 \mathrm{kgm}$.) which were previously treated

with $5 \mu \mathrm{gm}$. œstradiol benzoate per day for seven days.

The active unsaponifiable fraction of the oil does not contain iodine, which has been claimed to stimulate lactation ${ }^{9}$; neither does it contain nitrogen or sulphur.

It is clear that this lactation-stimulating compound is different from those compounds which are already known to stimulate lactation. Whether it acts through the pituitary or possesses suprarenal cortex. like activity, which is claimed to influence lactation ${ }^{10}$, or whether it acts directly, thus representing a new type of active material, is not at present known. Further investigations are being carried out by two of us (Ridi and Ayadi) and other collaborators.

\section{WADIE TADROS}

Chemistry Department, Faculty of Science, Fouad I University, Cairo.
M. S. EL-RIDI

M. A. S. EL-Ayadi

Biochemistry Department, Faculty of Medicine, Kasr-El-Aini, Fouad I University, Cairo.

July 9.

${ }^{1}$ Folley, S. J., Scott Watson, H. M., and Bottomley, A. C., J. Physiol., Proc., 98, 15 $p$ (1940).

${ }^{2}$ Folley, S. J., Malpress, F. H., and Young, F. G., J. Endocrinol., 4 181 (1945).

${ }^{3}$ Marx, L., Endocrinol., 37, 380 (1945).

' Tadros, W., J. Roy. Egyptian Med. A88oc., 30, 567 (1947).

${ }^{5}$ Hassan, A., and El-Ayadi, M. A., J. Roy. Egyptian Med. A8soc. 27, 236 (1944).

${ }^{6}$ El-Ridi, M. S., and El-Shahat, M., J. Roy. Egyptian Med. Assoc., 27, 258 (1944).

'Robson, J. M., J. Physiol.. 92, 371 (1938).

${ }^{3}$ Robson, J. M., J. Physiol., 88, 100 (1936).

- Robinson, M., Brit. Med. J., if, 126 '(1947).

${ }^{10}$ Robson, J. M., "Recent Advances in Sex and Reproductive Physiology" 270 (J. and A. Churehill, London, 1947).

\section{Recombination in Bacteria : Outcrossing Escherichia coli $\mathrm{K} / 2$}

THE discovery of recombination in Escherichia coli $i^{1,2}$ has given to bacterial genetics a much wider scope than it had before. Three years after its first publication, however, the results obtained by Leder. berg with the strain known as $K 12$ still stand alone, no other bacterial strain having been found to show a similar behaviour. This is partly due to the fact that demonstration of recombination is a slow business, owing to the work required for the preparation of suitable substrains. In fact, the only method known so far is still the original one of mixing substrains having different growth requirements on a minimal medium where neither parental strain can grow, but on which cells possessing some of the synthetic capacities of one strain and some of the other will be able to form colonies. As such colonies, called by Lederberg 'prototrophs', usually appear at a very low rate, care must be taken that recombination is not simulated by back-mutation in either parental strain.

In a programme of study of the extent and pro. perties of 'sexual' behaviour in bacteria, the first stage has been that of outcrossing Escherichia coli $K 12$ to other coli strains. In $K 12$, several multiple mutant substrains have been prepared by Lederberg, while in some other coli strains advantage may be taken of the fact that they show spontaneously simple or multiple growth-factor deficiencies, which are often suitable for use in demonstrating recombination.

Of thirty independent strains of Escherichia coli, tested for growth on minimal medium, ten showed 